the ground color considerably obscured by whitish pubescence, in shape broader than long, flattened above, its upper apex more acutely rounded than the lower; arista black, bare, considerably thickened basally for about one-third its length (not as much as in $C$. crassiseta of Europe), then suddenly thinned.

Thorax and scutellum shining greenish black, the dorsum with a slight brassy reflection, covered with moderately short fulvous pile, but a stripe of black pile from the humeri to the base of the wings, and some black hairs about the postalar callosities.

Abdomen metallic greenish black; first segment with an opaque area on each side; second segment opaque black, the sides shining, the lateral ends of the opaque only very slightly concave and a little broader posteriorly; the opaque on the third segment is a little narrower than that on the second, does not quite reach the posterior margin and is not at all concave laterally. Pile of abdomen wholly fulvous.

Legs black, tips of the femora, bases of the tibiae and the apices of the front four tibiae reddish; basal tarsal joints brownish. Wings distinctly luteous, more clouded across the middle; stigma luteous; the first posterior cell ends in an acute angle. Squamae whitish yellow fringed with pale yellow pile. Halteres reddish.

Holotype, \&., Orillia, Ontario, May 5, Ig2 I (Curran), in the writer's collection.

This species is related to crassiseta Becker of Europe, but the arista is not so much enlarged; differs irom capillata in black pile of head, truncate shape of opaque of the abdomen and lighter colored legs, the face almost similar in profile; from comosa in the shape of the opaque markings and brownish wings; from nigripennis and versipellis in having yellow pile on thorax, etc. ; from parva in the dark legs; from ontario in smaller size, different shaped antennae, arista, etc.

\title{
THE FAMILY POSITION OF PLATYPREPIA AND O'THER NOTES. (LEPID.)
}

BY HARRISON G. DYAR, A.M., PH.D.,

U. S. Tational Museum, Washington, D. C.

Some remarks by Dr. McDunnough seem to call for a little elucidation (Can. Ent., LIII, I67, I92I). I am quoted as claiming that Platyprepia belongs to the Hypsidae. This claim was not intended as original, as Dr. McDunnough's renarks seem to imply, but in following the established literature of the group it is well known that in Sir George Hampson's classic work, Platyprepia is omitted from the Arctiidae, together with Callimorpha (in the

Ed. Note.-The above article serves to elucidate Dr. Dyar's rather negative views in regard to the family position of Platyprepia but still leaves the correct position of this geuus in doubt. The fact remains that tine amastomosis of reinls 7 ankt 8 of secondaries in $P$. guttata, a so-called Hypsid, is as long as, or even longer than that found in Arctia caia, the typical Arctiid.

Author's Note.-In estimating the Iength of the anastomosis, I do not count from the lase of the wing to the point where reins 7 and 8 separate, which appears to be Dr. IIDunnough's standard, but from the point where reins 7 and 8 fusa to where they separate again. In Platyprepic, these roins are free at the base, anastomose for about $3 \mathrm{~mm}$, then seprate. In Arctia, they an united to the base, making the length of the anastomosis about $7 \mathrm{~mm}$. On this basis a more positive distinction can be made, and the lefer:nce of Platyprepia the Irvirlac retained. 
European sense) and the groups which we used to call Pericopidae, Nyctemeridae and Hypsidae. These we expect him to treat under the family Hypsidae (Callimorphidae), except that his labors unfortunately terminated with the Noctuidae. I do not recall any statement by Hampson that Platyprepia belongs to the Hypsidae; but this seemed the only possible inference from his work that had appeared. After 1902 I regarded it as negatively established, and hence my remark which Dr. McDunnough refers to was briefly made.

It is also true that Sir George defines the family Hypsidae by having vein 8 of the hind wings connected with the cell by a bar. This can be verified by any of the Hypsa proper, and the definition remains unchanged in his latest publication (Nov. Zool., xxv, 389, I918). However, in Callimorpha, the Nyctemeridae and Pericopidae the bar becomes a short anastomosis, as tacitly admitted by Hampson in his Moths of India (I894) where he places Nyctemera in the Arctiidae. The definition of the family thus becomes confused; but I have followed Sir George in his classification. Therefore Dr. McDunnough's remark that he would retain Platyprepia in "its present position in the Arctiidae" seems somewhat inappropriate, since Platyprepia has been omitted from the Arctiidae for the last twenty years by the most authoritative student of the world fauna, and not again restored by him in his latest reference (Cat. Lep. Phal. B. M., Suppl. vol. ii, I920). If Dr. McDunnough wishes to differ from Hampson, which of course he has the right to do, the question of Platyprepia widens to include all of the Pericopidae and Nyctemeridae, for there is no difference that I can perceive in the venation. The anastomosis is shorter in these forms than in the Arctiidae in general, and if a more or less short anastomosis can be called a bar, it is possible to follow Hampson's classification, and this I suppose it is better to do if possible. Uniformity in nomenclature is so desirable that we should stretch a point to conform, if it can be done. For these reasons I would let Platyprepia remain in the Hypsidae instead of transferring it to the Arctiidae as Dr. McDunnough proposes.

Dr. McDunnough further refers to a similarity of larvae and male genitalia; but this similarity probably runs through all the groups mentioned.

In the same article Dr. McDunnough refers the species alpina Quensel to Arctia after showing the generic separation from Hyphoraia. In this he agrees with Hampson, who made the same reference and separation previously (Cat. Lep. Phal. B. M., Suppl. ii, 500, 1920). Hampson does not record $A$. alpina from America; but the European Arctic Fauna is the same as the American Arctic, apparently entirely, as far as these forms are concerned.

\section{THE ENTOMOLOGICAL SOCIETY OF ONTARIO-ANNUAL MEETING}

The fifty-eighth Annual Meeting of the Entomological Society of Ontario was held at the University of Toronto during the week of December the twentyeighth. The meeting was held at this time in order to afford our members an opportunity of meeting with the members of the Entomological Society of America and of the American Association of Economic Entomologists. 